\title{
Strategies to address learner aggression in rural South African secondary schools
}

\begin{tabular}{|c|c|}
\hline \multicolumn{2}{|c|}{$\begin{array}{l}\text { Authors: } \\
\text { Gunam D. Singh }{ }^{1} \\
\text { Gertruida M. Steyn }{ }^{1}\end{array}$} \\
\hline \multicolumn{2}{|c|}{$\begin{array}{l}\text { Affiliations: } \\
\text { 1Department of } \\
\text { Educational Leadership and } \\
\text { Management, University of } \\
\text { South Africa, South Africa }\end{array}$} \\
\hline \multicolumn{2}{|c|}{$\begin{array}{l}\text { Correspondence to: } \\
\text { Gertruida Steyn }\end{array}$} \\
\hline \multicolumn{2}{|c|}{$\begin{array}{l}\text { Email: } \\
\text { steyngm1@unisa.ac.za }\end{array}$} \\
\hline \multicolumn{2}{|c|}{$\begin{array}{l}\text { Postal address: } \\
\text { PO Box 392, Pretoria 0003, } \\
\text { South Africa }\end{array}$} \\
\hline \multicolumn{2}{|c|}{$\begin{array}{l}\text { Dates: } \\
\text { Received: } 03 \text { Dec. } 2012 \\
\text { Accepted: } 19 \text { June } 2013 \\
\text { Published: } 08 \text { Nov. } 2013\end{array}$} \\
\hline \multicolumn{2}{|c|}{$\begin{array}{l}\text { How to cite this article: } \\
\text { Singh, G.D. \& Steyn, G.M., } \\
\text { 2013, 'Strategies to address } \\
\text { learner aggression in rural } \\
\text { South African secondary } \\
\text { schools', Koers - Bulletin for } \\
\text { Christian Scholarship 78(3), } \\
\text { Art. \#457, } 8 \text { pages. } \\
\text { http://dx.doi.org/10.4102/ } \\
\text { koers.v78i3.457 }\end{array}$} \\
\hline \multicolumn{2}{|c|}{$\begin{array}{l}\text { Note: } \\
\text { This article reports on part of } \\
\text { an investigation conducted } \\
\text { for a Master's dissertation, } \\
\text { by Singh (2012). }\end{array}$} \\
\hline \multicolumn{2}{|c|}{$\begin{array}{l}\text { Copyright: } \\
\text { (C) 2013. The Authors. } \\
\text { Licensee: AOSIS } \\
\text { OpenJournals. This work } \\
\text { is licensed under the } \\
\text { Creative Commons } \\
\text { Attribution License. }\end{array}$} \\
\hline \multicolumn{2}{|l|}{ Read online: } \\
\hline 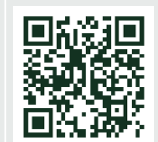 & $\begin{array}{l}\text { Scan this QR } \\
\text { code with your } \\
\text { smart phone or } \\
\text { mobile device } \\
\text { to read online. }\end{array}$ \\
\hline
\end{tabular}

Managing learner aggression in the school system is central to learners' academic performance and holistic development. In order to manage learner aggression, it is important to understand the contributory factors and the forms of learner aggression. This article reports on an investigation of factors contributing to learner aggression in rural secondary schools in the Empangeni district of KwaZulu-Natal in order to identify the forms of learner aggression and to establish strategies to manage such aggression in these secondary schools. A qualitative research design was adopted to investigate the phenomenon through an interview process with participants from five rural secondary schools. The findings showed that the factors contributing to learner aggression include family factors, environmental factors and school-related factors whilst the most common forms of learner aggression in schools are verbal aggression, physical aggression and bullying. The article concludes with the role that the school, parents and the Department of Education can play in addressing learner aggression in schools.

Strategieë om leerderaggressie in landelike Suid-Afrikaanse sekondêre skole aan te spreek. Die hantering van leerderaggressie in die skoolstelsel is deurslaggewend vir leerders se akademiese prestasie en holistiese ontwikkeling. Om leerderaggressie te bestuur is dit belangrik om die bydraende faktore en die vorme van leerderaggressie te verstaan. Hierdie artikel rapporteer oor die bevindings van 'n ondersoek waar gefokus is op faktore wat tot leerderaggressie in landelike sekondêre skole in die Empangeni-distrik van KwaZuluNatal bydra. Die doel daarvan was om vorme van leerderaggressie te identifiseer sodat geskikte strategieë ontwerp kan word om leerderaggressie die hoof te bied. 'n Kwalitatiewe navorsingsontwerp het die onderhoudproses in vyf landelike sekondêre skole gelei. Daar is bevind dat gesins-, omgewings- en skoolfaktore die algemeenste oorsake vir leerderaggressie vorm. Voorts is verbale aggressie, fisiese aggressie en afknouery as die algemeenste vorme van leerderaggressie geïdentifiseer. Die artikel sluit af met die rol wat die skool, ouers en Departement van Onderwys kan speel om leerderaggressie te beperk.

\section{Introduction}

The Bill of Rights of the Constitution of the Republic of South Africa, (Republic of South Africa 1996a:ch. 2:24a) guarantees a safe environment for all citizens (Republic of South Africa n.d.). Schools are integral community-based organisations that ought to be safe havens for all stakeholders in order for teaching and learning to take place without interruption. However, in practice, this is not the case. Schools have become hotspots for crime and violence, often as a result of learner aggression. Not surprisingly, Balt (2008:8) asserts that learner aggression and violence at school contribute to stress and low morale amongst staff.

Significantly, studies have found that domestic violence affects children emotionally, socially, physically and behaviourally (Szyndrowski 2005:10). Accordingly, adolescents who have experienced family violence, either as victims or witnesses, are likely to have negative feelings about their parents and to end up being aggressive (Spillane-Grieco 2000:427).

The abovementioned factors make it difficult to provide for learners and teachers a safe environment in which effective teaching and learning can take place. In fact, the violent acts perpetrated by aggressive youths impact negatively on the ethos of the school, compromise the safety of learners and teachers and, in turn, adversely affect teaching and learning in the classroom (Naran 2006:8). It follows that, without effective behaviour management, a positive and productive classroom and school environment will be impossible to achieve (Lewis et al. 2008:715). Strong, committed leadership involving all stakeholders of the school system is urgently needed to attend to the scourge of learner aggression in schools.

The main purpose of the study by Singh (2012), on which this article is based, was to examine the contributing factors to learner aggression as well as the forms of learner aggression in rural 
secondary schools and, on the basis of the findings, to formulate strategies that could be employed to manage the problem of aggression in secondary schools.

\section{Theoretical framework}

In this study, different theories and models related to learner aggression are used to interpret the findings of the empirical investigation. The social-learning theory that is advocated by Albert Bandura emphasises that aggressive behaviour is learned and maintained through environmental experiences (Renfrew 1997:152).

The social-learning approach complements the respondent and operant mechanisms of behavioural theory, which emphasises the learning of aggression within a social context (Moeller 2001:29). Social-learning theorists argue that aggression can be learned, maintained as well as unlearned through the processes of classical and operant conditioning and through rewards and punishment.

Buss's theory of aggression is also considered as it highlights the two common forms of aggression in schools, namely vicious verbal and physical attacks (Bandura 1973:149). Also relevant is Dollard's frustration-aggression theory, which states that learners are motivated to behave aggressively by a frustration-produced drive. When learners are frustrated by their personal negative circumstances, aggressive energy is created and that energy activates dominant aggressive responses (Bandura 1973:31-33).

Apart from these theories, various models of disruptive behaviour have been explored to reduce the problem of learner aggression in rural secondary schools.

The biopsychosocial model suggests a moderate degree of heritability for delinquent, disruptive and antisocial behaviour from childhood to adulthood (Dodge \& Pettit 2003:350). The medical model proposes that disruptive behaviour is the result of maladjustment in children; therefore they need to be referred to child-guidance clinics for therapy (Jones 2003:147). Furthermore, the educational model states that emotional and behavioural difficulties can be addressed by teachers who are able to use systemic insights and particular intervention techniques to modify the behaviour of disruptive learners (Jones 2003:154). The teaching-pyramid model proposes a three-tiered model of classroom strategies for promoting the social-emotional development of children with challenging behaviour (Fox et al. 2003:48).

However, the model that requires in-depth investigation is the action-research model of consultation and collaboration since this model posits that behavioural consultation and collaboration amongst all stakeholders of the school system are necessary processes in the endeavour to help children with disordered conduct (Conwill 2003:239).

\section{Problem statement}

The Empangeni district of KwaZulu-Natal, South Africa, comprises mainly rural schools. Many of these schools have experienced criminal activity arising from learner aggression to the extent that teaching and learning have been negatively affected (Naidoo 2008:1). Furthermore, both the teachers and the learners have become targets of intimidation by the aggressive youth.

In the interaction with the principals and teachers of the local secondary schools concerned, it became clear that they are too scared to teach in these schools. Because of this fear, many suffer from stress and depression and absent themselves from school for long periods. In addition, teachers are resigning from their jobs because they are victims of psychological and physical violence perpetrated by the learners (Dibetle 2008:7).

Victims are bullied, threatened, beaten or even sexually assaulted. Consequently, they display feelings of helplessness, humiliation, disappointment, a poor self-concept, low selfesteem and depression. Learner aggression will continue to pose a problem in schools until necessary strategies are found to curb and prevent aggressive episodes from taking place in schools. Emanating from the above, the main research questions addressed in this study were: 'What are the causes of learner aggression and how can learner aggression in rural secondary schools in the Empangeni district of KwaZuluNatal be managed successfully?'

\section{Research methodology}

Five rural secondary schools in the Empangeni district of KwaZulu-Natal with a history of aggression-related problems were purposefully selected as sites for the investigation. Incidents concerning aggressive behaviour by learners in these schools reported in the local media as well as complaints from teachers and management staff of these schools provided the impetus for the inquiry.

The principals of the five secondary schools were interviewed to ascertain a management perspective on the problem. Focus-group interviews with eight teachers from each school were conducted to gain the teachers' perspective whilst focus-groups interviews with eight learners representing the Representative Council of Learners (RCL) from each school were conducted to ascertain learners' perspective.

A qualitative design was deemed most appropriate for the study because it could give a clear understanding of the participants' views and it could capture participants' perceptions in their own words (Johnson \& Christensen 2011:18). The design involved both an interpretive perspective, because it was primarily concerned with meaning, and a constructivist perspective, because it focused on the feelings and beliefs of the participants (McMillan \& Schumacher 2010:347). In order to capture responses of participants, all interviews were tape-recorded and later transcribed verbatim.

In this study, Lincoln and Guba's model for ensuring the trustworthiness of qualitative data was employed according to the following four criteria (Poggenpoel 1998:349-351): truth value, applicability, consistency and neutrality. In the 
data analysis, segments of data were identified by means of symbols and category names.

The ethical measures included the permission from the KwaZulu-Natal Department of Education and permission from the school principals before entering their premises to collect data since obtaining permission from organisational personnel requires contacting them before the start of the study (Creswell 2002:160). Likewise, informed consent from all the prospective participants (principals, teachers and learners) was obtained, and their confidentiality was assured (Johnson \& Christensen 2011:107).

\section{Findings}

In order to analyse and interpret the raw data, a qualitative data-analysis process was followed where the information was coded and categorised (Creswell 2002:258). This was done in conjunction with the aim of the study that guided the development of the main themes, categories and subcategories and that subsequently assisted in content analysis and interpretation (Wiersma \& Jurs 2005:216). The empirical findings are supported by a literature study on the various theories of aggressive behaviour. For the purpose of the study, the following main themes were identified:

- factors contributing to learner aggression

- forms of learner aggression

- management of learner aggression in schools.

\section{Factors contributing to learner aggression}

The data revealed three core factors contributing to learner aggression: family factors, environmental factors and school factors.

\section{Family factors}

According to most of the participants, the learner's family background, which included broken homes, poverty and poor parenting, is a key contributing factor to learner aggression.

Broken homes: The interviews confirmed that most learners who displayed aggressive tendencies came from broken homes. One principal (School A) succinctly explained:

'Most of our learners come from very broken families ... most of the parents are single parents, mainly mothers ... the boys will then take on the responsibility of being the main man in the house ... and have this bossy character.'

These findings are in keeping with behavioural theory, which emphasises the learning of aggression within a social context (Moeller 2001:29), and Dollard's frustration-aggression theory, which postulates that learners are frustrated by their personal negative circumstances (Bandura 1973:31-33). The study also highlighted poverty as another key element that contribute significantly to antisocial learner behaviour.

Poverty: Responses from the participants showed that poverty is another key element that contributes significantly to antisocial learner behaviour. The principal of School E maintained:
'Most of these learners come from poor families and then there are things they could not afford to have and once they come to school, they come carrying that anger within. Such children, the have-nots, usually turn to bullying those children who are well-to-do.'

These findings confirm Dollard's frustration-aggression theory, which propounds that frustration produces aggressive energy that activates aggressive behaviour. Robbins (2001:61) confirms that poorer children are more likely to experience greater stress due to life events. Apart from poverty, poor parenting also contributes to disruptive antisocial behaviour.

Poor parenting: The findings from the study confirmed that parents who are unable to instil proper discipline in their children contribute to their disruptive behaviour. As one of the principals (School D) explained: 'I'm beginning to believe that [disruptive] behaviour ... might be because parents might not be responsible enough.' As a learner (School A) explained:

'Some learners are raised by parents who take alcohol and once they are drunk ... they solve their problem by fighting. And some of them [learners] even come to school intoxicated.'

The abovementioned findings support Bandura's sociallearning theory, which demonstrates how a modelling process is responsible for learning aggressive behaviour. The continued exposure to acts of violence is likely to induce a process of imitation, culminating in the acceptance of violent conduct as a normal mode of conflict resolution (Govender \& Killian 2001:1).

The study also found that the learners' exposure to the environments in which they were brought up played a critical role in shaping their behaviour.

\section{Environmental factors}

The views expressed by the participants strongly suggest that environmental factors play a key role in learner aggression. These views are presented in this subsection.

Drug and alcohol abuse: The principals of all five secondary schools that formed part of the study (i.e. Schools A-E) lamented the adverse consequences that the use of drugs and alcohol has in their schools. Sentiments expressed in this regard included the following: 'Drug trafficking is prevalent in this school' (principal, School D) and '[t]he children are so addicted to the substance [marijuana] that when the craving arises they need to have a smoke or two' (teacher, School A). A learner (School B) confirmed that drugs were used on the school premises, 'I've seen it and ... consuming alcohol ... I've seen it.'

These findings concur with Bandura's social learning theory, which emphasises external environmental cues as elicitors of aggression. Valois et al. (2002:459) support this theory by stating that the availability of drugs and alcohol influences a culture of aggression and violence amongst children. It was found that peer pressure is one of the chief causes of drug and alcohol abuse, which contributed significantly to learner aggression. 
Peer pressure: In order to impress their peers, learners behave aggressively towards victims, for which the reward was acceptance into the group. The punishment for noncompliance is peer rejection, which resulted in exclusion from the group. A learner (School B) expressed the following: 'The causes are mainly peer pressure as they [learners] want to fit in.' A similar view was propounded by a principal (School C) who stated: 'Whoonga (drug) and dagga (marijuana) are freely available ... and if you don't do it, you're not identified as one of the cliques.'

The findings are supported by the biopsychosocial model of aggression, which proposes that, because of modelling effects, the amount of exposure a child has to aggressive peers is predictive of disruptive behaviour (Dodge \& Pettit 2003:353). It is therefore clear that aggressive acts are committed through affiliation with deviant peers in order to be accepted into a group or gang.

Gangsterism: The participants highlighted the influence of gangsters and maintained that gangsterism is 'rife' in schools. As a teacher (School B) confirmed: 'We also have the problem of gangsterism ... There are groups that ... want to meet their mates from school during lunch breaks and pedal drugs.' A learner (School D) elaborated:

'... there's this guy ... he belongs to a gang ... every time when he drinks, he'll come back to class, chasing girls, beating them, breaking desks or even doors and windows.'

The abovementioned findings are in keeping with Bandura's social learning theory in which he asserts that, once people have witnessed another's behaviour, they may be inclined to adopt this behaviour as their own. Hence, aggression can increase due to exposure to aggressive role models (Robbins 2001:56). Apart from the existence of gangs, racism is also responsible for fuelling learner aggression.

Racism: Although all schools in South Africa have become multiracial institutions since 1994, the problem of racism persists as is clear from a teacher's (School B) testimony: 'We as Indians have to teach a large number of black pupils and they tend to be aggressive towards us. They do not want to take instructions from us.' Many participants believed that different cultures in the school often lead to discrimination and disrespect amongst the different races.

These views concur with Buss's theory of aggression that relates aggressive behaviour to antecedent experiences specifically related to past frustrations (Buss 1961:28). Maree (2000:4) states that the intolerance of learners towards people of other races can contribute significantly to learner aggression in schools. Besides environmental factors, school factors contribute considerably to learner aggression.

\section{School factors}

Factors at school, such as age cohort, corporal punishment, teenage pregnancy and poor management structures, play a major role in promoting aggressive behaviour.
Age cohort: Evidence from participants confirmed that age is a major factor that contributes to learner aggression. A teacher (School B) explained: 'Many learners [who display aggression] are ... much older than other learners in the grade.' In fact, some learners are bigger than their teachers.

The data above confirms Dollard's frustration-aggression theory, which posits that frustration, which is an aversive stimulus, produces aggressive energy. The inability of older learners to pass causes considerable frustration that is then expressed in hostile, aggressive outbursts against younger, vulnerable learners (Olweus 2005:9). Apart from age cohort, many participants highlighted teenage pregnancy as another significant cause of learner aggression.

Teenage pregnancy: Findings from the interviews confirmed that teenage pregnancy is a serious problem in KwaZuluNatal schools, especially in rural areas. In School D alone, the principal reported that there had been 10 pregnancies during 2011. A teacher (School A) explained how pregnancy caused aggression in female learners: '...one of the parents told me her daughter is pregnant ... her whole character has changed ... she has become very difficult to control.'

The findings confirm Buss's theory of aggression, which states that frustration is the cause of a number of different types of responses, one of which is aggression (Buss 1961:28). Shaffer and Kipp (2010:234) affirm this theory by stating that pregnant teens are more likely to be involved in incidences of violence than non-pregnant teens. The aggression experienced by pregnant schoolgirls is exacerbated by teasing, gossiping and jealousy.

Teasing, gossiping and jealousy: A number of participants agreed teasing does indeed lead to aggression. Accordingly, a teacher (School A) summed up this problem as follows: '... they start teasing each other and then they start fighting.' Furthermore, rumours and gossiping lead to learners displaying aggressive attitudes towards their peers. A learner (School B) explained:

'This older girl accused my friend of spreading rumours about her ... this girl just brought her friends and started arguing with my friend ... and the fight just went on and on and on.'

With regard to jealousy, a learner (School D) referred to a boy who often became jealous and eventually aggressive when others received better grades than he did.

The findings are in keeping with Dollard's frustrationaggression theory. He argues that, if a person is constantly frustrated by aversive stimuli (in this case, teasing, gossiping and jealousy), the self-reinforcement increases the likelihood of aggressive behaviour (Felson \& Tedeschi 1993:41).

Poor school-management structures: Participants strongly felt that poor school-management structures contribute significantly to learner aggression. This was strongly expressed by a learner (School A), 'I think that the structures [disciplinary structures] and the manner of doing things are very distorted and that's why we don't see order in any way.' 
The empirical findings confirm Bandura's social-learning theory that emphasises that aggression can be acquired, maintained and allowed to flourish when poor management structures exist in schools (Renfrew 1997:152).

The various causes of learner aggression explained above are manifested in different forms of learner aggression.

\section{Forms of learner aggression}

The findings of the empirical investigation revealed that physical aggression, verbal aggression and bullying are the most common forms of aggression in these schools.

Physical aggression: Fighting and physical assaults were reported as the main forms of learner aggression. This aggression took the form of learner-on-teacher as well as learner-on-learner aggression. A principal (School A) related an incident of physical aggression in his school: 'A boy stole the exam paper from the teacher's bag ... and when the teacher asked him to return the paper, the boy refused. Instead, he wanted a fight!'

Anther principal (School B) complained about learner-onlearner aggression at his school, citing the following example: 'The case was a physical kind of an aggression where a learner was ... continuously ... referred to my office for fighting and hitting certain learners in the classroom.'

The above findings confirm Buss's theory of aggression, which emphasises that behaviour is considered aggressive when one individual is responsible for providing noxious stimuli to another person (Buss 1961:28). Fraczek and Zumkley (1992:4) validate this theory by asserting that aggressive behaviour is directed towards causing harm to others. Often, physical fighting occurs, following on extreme verbal aggression by learners.

Verbal aggression: Participants confirmed that verbal aggression is another common form of aggression in their schools. A teacher (School A) contended that, if 'he [the learner] did not have any books, he would scream and swear and pass remarks the entire time.' A similar incident was shared by another teacher (School D): 'Worst of all, he wouldn't hesitate to insult you in the local language.'

The above expositions confirm Buss's theory of aggression, which highlights verbal aggression as a vocal response that provides malicious stimuli in terms of rejection, threats and insults (Buss 1961:28).

Bullies, who are the chief perpetrators of aggressive behaviour, often use indirect and relational bullying and social exclusion in threatening and harassing victims into submission.

Bullying: The data confirmed that bullying is a chronic problem in the schools and that it does not only take place on the school playgrounds and in the corridors and classrooms but also before and after school on the school bus and in other forms of transport. A learner (School A) related an incident in which bigger learners bullied smaller children in the bus. Another learner (School A) added: 'This guy pushed me to the back of the class, took an elastic band and he wanted to strangle me with an elastic band.'

The abovementioned findings confirm Buss's theory of aggression in which he emphasises the use of instrumental aggression, which includes direct aggression that occurs in the presence of and is aimed at the victim, and active aggression, which requires an instrumental response that delivers noxious stimulation to the victim (Buss 1961:28). This concurs with the views espoused by Moeller (2001:220) that bullying occurs when a more powerful person repeatedly imposes aggression on a less powerful person.

With the abovementioned forms of aggression inhibiting the provision of a climate conducive to quality teaching and learning, it became imperative to identify strategies to curb aggression in rural secondary schools.

\section{Strategies to curb learner aggression in schools}

Responses from the participants proved conclusively that structures to manage aggression in schools were inadequate, ineffective or even non-existent at some schools. In this regard, participants highlighted the role of schools, parents and the Department of Education in addressing learner aggression in schools.

\section{The role played by schools}

In line with the provisions of the 1996 South African Schools Act (Republic of South Africa 1996b), schools should play a major role in addressing learner aggression.

Code of conduct: Participants confirmed that a code of conduct is available in schools, but it is not implemented effectively. The principals who are implementing these codes of conduct complained of their ineffectiveness. A learner (School A) felt strongly that the code of conduct needs serious overhauling since even the highest level of sanction, which is suspension, is ineffective. Moreover, some participants believed that the code of conduct is too lenient, thereby compromising the management of learner aggression.

In this regard, the action-research model of consultation and collaboration encourages the involvement of all stakeholders of the school in curbing learner aggression. In keeping with this view of consultation, Rossouw (2007:82) pointed out that a code of conduct is a consensus document, and its drafting process should be characterised by the involvement of parents, learners, teachers and non-teachers at the school.

Furthermore, every school must have a disciplinary committee to discipline learners who commit serious misdemeanours.

Disciplinary committees: The participants from schools A, B, C and E confirmed that their schools do have elected disciplinary committees to handle discipline issues. A 
teacher (School E) confirmed the existence of a disciplinary committee at his school, but complained about its ineffective functioning:

'The committee is supposed to be working hand in glove with the community ... with the parents ... with the police, with social workers ... but maybe we don't do much in these committees.'

Rossouw (2007:80) maintains that disciplinary committees should ensure that positive discipline and self-discipline are promoted and that exemplary conduct should be rewarded to the same extent as punishment of misconduct. This view is in keeping with the behavioural theory, which emphasises that aggressive behaviour can be learned and unlearned through the process of classical and operant conditioning and through rewards and punishments (Moeller 2001:29).

The school-governing body: According to Joubert and Squelch (2005:23), the school-governing body (SGB) can and should play an important role in the establishment and maintenance of sound discipline. The participants were in agreement that the school-governing body should play a key role in addressing learner aggression. A principal (School B) stated: 'When it comes to learner discipline, [the SGB] should make sure that all the aggressive learners are dealt with according to a clear disciplinary process.'

The findings above are supported by the action-research model of consultation and collaboration, which posits that behavioural consultation and collaboration amongst stakeholders are necessary processes in the endeavour to help children with disorderly conduct.

The study also emphasised the key role that teachers need to play to address learner aggression in schools.

The role of teachers: A teacher (School A) believed that his 'counselling background' plays a key role in assisting aggressive learners. Another teacher (School D) was of the opinion that aggressive learners 'need attention, so you give them the special attention and everybody is safe', which she regarded as her 'personal strategy'.

Since behavioural psychology emphasises the fact that behaviour is learned, teachers are equipped to help afflicted children learn new and more appropriate behaviour (Cooper, Smith \& Upton 1994:37). This is in line with the educational model, which places the responsibility for the identification of disruptive learners and the implementation of intervention strategies squarely on the school with teachers playing a pivotal role in the learners' behaviour modification and rehabilitation.

Equally important in assisting the school in addressing the problem of learner aggression is the involvement of parents in their children's behaviour.

The role of parents: Many participants held the view that parents are a vitally important part of the school system and do have an important responsibility to assist principals and teachers to reduce the incidence of disciplinary problems in the school through their active involvement. However, teachers complained of the non-involvement of parents in school-related matters. A teacher (School B) commented:

'... the actual parent support is lacking, they either refuse, or say "I'm not available, I'm at work" or some place ... the apathy, the tremendous apathy among the majority of our parents ... you find that parents are simply just not available and this compounds the problem.'

The abovementioned findings support Bandura's socialcognitive theory, as discussed, which posits that parents are influential in ensuring either positive or negative outcomes for their children at school. This theory emphasises that parents who raise their children in a caring, supportive environment can certainly contribute to their children's abilities. However, when parents lack interest in their children, they may instil negative behaviour in them. Bemak and Keys (2000:17) concur with this theory by maintaining that learner aggression escalates because of poor parent supervision.

Apart from parents, the RCL is well placed to assist the management team to reduce learner aggression in schools.

The role of the representative council of learners: The RCL is a democratically elected structure in secondary schools whose chief responsibility is to assist the school management. Learners in all five schools gave both positive and negative feedback concerning the involvement of RCLs in their schools as far as it relates to combating learner aggression. A learner (School A) stated:

'What I really appreciate about the RCLs, [is] the way they handle learner aggression at school. First of all, they understand it far better than the teachers. They put themselves there because they are in that age group.'

However, other members of the RCLs of the five schools differed completely in their opinions of the RCL as a structure. They complained bitterly about not knowing what to do when problems arose because of a lack of training, indicating that they were scared to take the matter up for fear of victimisation.

One of the principals (School D) expressed deep concern about the negative effects that the democratic election of RCL members have on the school:

'Most unfortunately, when these RCL members are elected ... you never get responsible people. In 2007, I had a president of the RCL who was so chaotic, that he was even robbing learners of their money. He was the one who was encouraging learners to go to the nearby shebeens.'

Even though these views give a mixed response regarding the functioning of and need for a RCL in schools, the body has a legitimate role to play in school governance. This is in keeping with Conwill's action-research model of consultation and collaboration that proposes that consultation and collaboration amongst all stakeholders of the school are necessary processes in the endeavour to help children with behavioural problems (Conwill 2003:239).

Apart from the school, the role of particularly the Department of Education in providing effective support to schools is critical in reducing learner aggression in schools. 


\section{The role of the Department of Education}

The participants believed that the Department of Education could play a pivotal role in providing schools with direction in respect of managing difficult and aggressive learners. The participants were of the opinion that schools do not receive the 'desired assistance' and that the department's 'intervention has been lacking, let's put it at zero'.

Based on the findings regarding the role of the Department of Education, a number of recommendations are made.

Reviewing and monitoring the implementation of the code of conduct for learners: According to the 1996 South African Schools Act (Republic of South Africa 1996b, s. 8[3]), 'the Minister may, after consultation with the Council of Education, determine the guidelines for the consideration of governing bodies in adopting a code of conduct for learners'. It is against this background that there is an urgent need to review schools' code of conduct to include tougher sanctions even though the South African Schools Act insists that the code of conduct must promote positive discipline and thereby facilitate constructive learning, and not be punishment-orientated and punitive. Moreover, even though expulsion, according to South African Schools Act (Republic of South Africa 1996b), is a function of the head of the provincial Department of Education, it is recommended that the powers of the disciplinary committee of the school be extended to include decisions to transfer wayward learners and even implement expulsion in extreme circumstances so that a stronger approach is adopted.

Ensuring that the disciplinary committees are properly constituted and functional: The SGB has to appoint a disciplinary committee to conduct disciplinary inquiries (Department of Education 2003:25). However, during the interviews, the participants confirmed the existence of such structures at schools but complained about their non-functionality and ineffectiveness. In this regard, it is recommended that committees such as the RCL, the Teaching and Learning Committee and the School Management Team meet at least once a month to address challenges related to aggressive learners at school. It is further suggested that the disciplinary committee, which consists of the parent component, should also meet regularly to attend to and take decisions regarding aggressive learners referred to them by the school. These meetings need to be closely monitored by the school principal to ensure that they do take place according to the set dates and timeframes.

Psychological services for all schools: At school level, it is strongly recommended that a lay counsellor be appointed in every school. A principal (School B) expressed the dire need for counsellors: 'In a circuit that is made up of more than 450 schools... there is only one psychologist ... to assist learners.' In addition, another principal (School C) expressed similar sentiments about counselling services: 'Previously in schools, we had guidance counsellors ... Now we don't have that situation.' The responses revealed that, in addition to the teachers' efforts to minimise disruptive behaviour in the classroom, support services should visit schools regularly to assist with behaviour modification for disruptive learners. In this regard, the action-research model of consultation and collaboration is ideally suited to be implemented through consultation with all the stakeholders, including mental-health professionals, teachers, parents and schoolmanagement teams.

The availability of support centres in every ward: With the annual budgetary constraints being experienced by the Department of Education and because of the large number of schools that need to be serviced, participants were aware of the fact that it may be difficult for every school to have its own psychologist. They therefore suggested that every ward should have a fully equipped support centre with qualified psychologists and social workers to service the schools within its boundaries. The participants' response support the medical model of disruptive behaviour that purports that disruptive behaviour is understood as a maladjustment, where the child needs to be removed and placed in a 'treatment environment' by trained psychologists and social workers (Jones 2003:148).

Based on the findings in the study, Figure 1 represents the factors contributing to learner aggression, their manifestation and how aggression can ultimately be managed in schools.

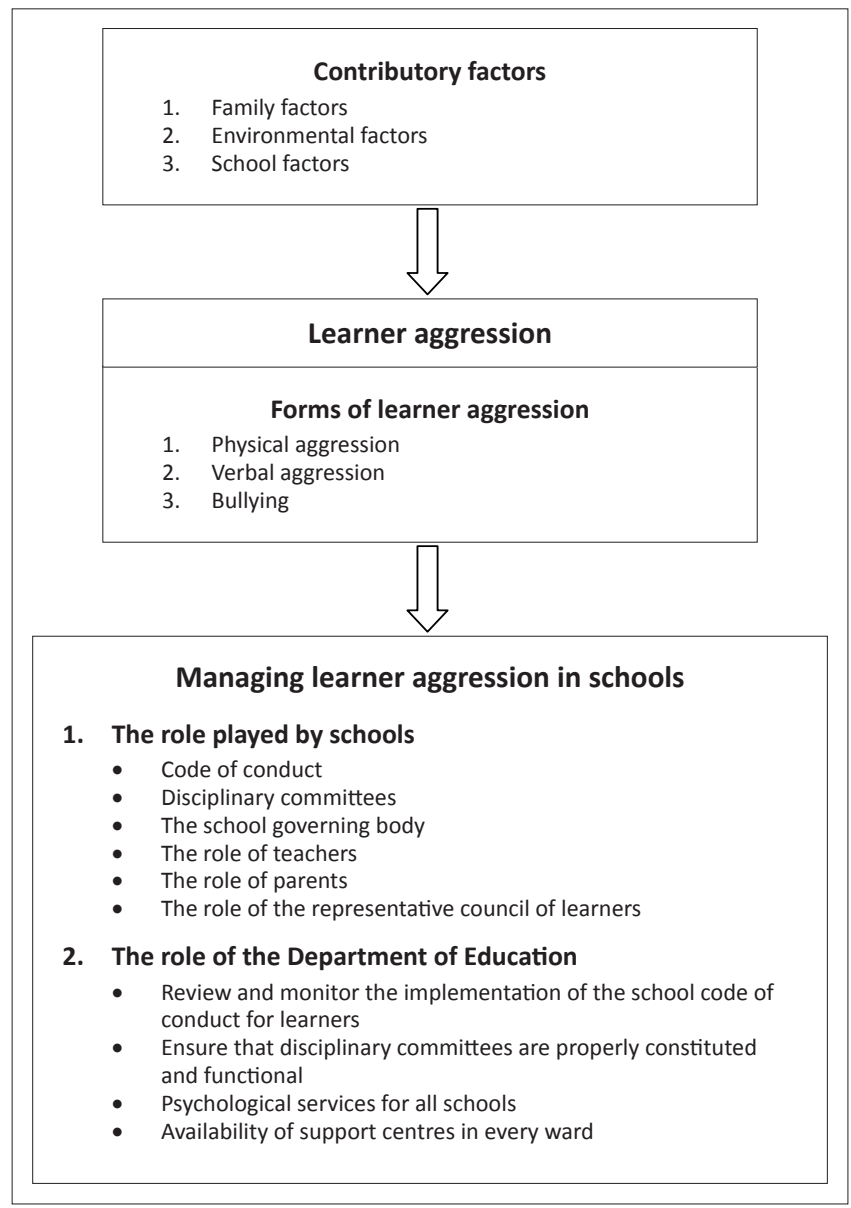

FIGURE 1: The factors contributing to learner aggression, their manifestation in schools and ways in which to manage learner aggression. 


\section{Conclusion}

The study found that learner aggression affects all the stakeholders at the school, namely the principals, teachers, parents and learners themselves. If aggression is considered an acceptable norm amongst learners, it is expected of everyone to conform to this culture. Should aggression become an acceptable norm amongst learners, it is necessary for all role players to address this unacceptable culture. The study which this article reports on set out to determine the forms and causes of learner aggression in rural secondary schools.

Learner aggression militates against the provision of a safe school environment for learners and teachers in which effective teaching and learning can take place. In fact, the entire school community can be affected negatively by this behaviour because the violence stemming from learner aggression can result in compromising the ethos of the school as well as its functionality. Irrespective of its origin, nature or progression, the violence emanating from learner aggression has catastrophic and dire consequences for teachers, parents and learners in particular. The study presented a number of managing strategies to address learner aggression. Without such solutions, learner aggression has the potential to create turmoil in schools and ultimately render schools ungovernable.

\section{Acknowledgements Competing interests}

The authors declare that they have no financial or personal relationship(s) that may have inappropriately influenced them in writing this article.

\section{Authors' contributions}

G.D.S. (University of South Africa) and G.M.S. (University of South Africa) contributed equally to the writing of this article.

\section{References}

Balt, D., 2008, 'The status of educators', Education Southern Africa: Lifelong Learning $1(10), 8-10$.

Bandura, A., 1973, Aggression: A social learning analysis, Prentice-Hall, Englewood Cliffs.

Bemak, F. \& Keys, S., 2000, Violent and aggressive youth: Intervention and prevention strategies in changing times, Corwin Press, Thousand Oaks.

Buss, A., 1961, The psychology of aggression, John Wiley \& Sons, New York. http:// dx.doi.org/10.1037/11160-000, PMid:13689382

Conwill, W.L., 2003, 'Consultation and collaboration: An action research model for the full-service school', Consulting Psychology Journal: Practice and Research 55(4), 239-248.

Cooper, P., Smith, C.J. \& Upton, G., 1994, Emotional and behavioural difficulties: Theory to practice, Routledge, London.
Creswell, J.W., 2002, Educational research: Planning, conducting, and evaluating quantitative and qualitative research, Pearson Education, Upper Saddle River. Department of Education, 2003, Policy handbook for educators, Government Printer,
Pretoria.

Dibetle, M., 2008, 'When school isn't safe', The Teacher 13(4), 5-7.

Dodge, K.A. \& Pettit, G.S., 2003, 'A biopsychosocial model of the development of chronic conduct problems in adolescence', Journal of Development Psychology 39(2), 349-371.

Felson, R.B. \& Tedeschi, J.J., 1993, Aggression and violence: Social-interactionist perspectives, American Psychological Association, Washington, DC. http://dx.doi. org/10.1037/10123-000

Fox, L., Dunlap, G., Hemmeter, M.L., Joseph, G.E. \& Strain, P.S., 2003, 'The teaching pyramid: A model for supporting social competence and preventing challenging behaviour in young children', Young Children 58(4), 48-53.

Fraczek, A. \& Zumkley, H., 1992, Socialization and aggression, Liveright, New York.

Govender, K. \& Killian, B.J., 2001, 'The psychological effects of chronic violence on children living in South African townships', South African Journal of Psychology 31(2), 1-24.

Jones, R.A., 2003, 'The construction of emotional and behavioural difficulties', Educational Psychology in Practice 19(2), 147-157.

Johnson, B. \& Christensen, L., 2011, Educational research: Quantitative, qualitative, and mixed approaches, 3rd edn., Sage Publications, Thousand Oaks.

Joubert, R. \& Squelch, J., 2005, Learner discipline in schools, 2nd edn., Centre for Education Law and Policy, Pretoria.

Lewis, R., Romi, S., Katz, Y.J. \& Qui, X., 2008, 'Students' reaction to classroom discipline in Australia, Israel, and China', Teaching and Teacher Education 24, 715-724.

Maree, K., 2000, 'What cannot be endured must be cured: Untying the Gordian knot in South African schools', Acta Criminologica 13(3), 1-13.

McMillan, J.H. \& Schumacher, S., 2010, Research in education: Evidence-based inquiry, 7 th edn., Pearson Education, Boston.

Moeller, T.G., 2001, Youth aggression and violence: A psychological approach, Lawrence Erlbaum Associates, Mahwah.

Naidoo, T., 2008, 'Schoolyard thugs strike in Chatsworth', Sunday Times Extra, 07 September, p. 1.

Naran, J., 2006, 'Learning fear at school', Tribune Herald News, 08 October, p. 8.

Olweus, D., 2005, 'Bullying/victim problems among school children: Basic facts and effects of school based intervention program', in D. Peplar \& K. Rubin (eds.), The developmental treatment of childhood aggression, pp. 411-448, Hillsdale, Erlbaum.

Poggenpoel, M., 1998, 'Data analysis in qualitative research', in A.S. de Vos, H. Strydom, G.B. Fouche, M. Poggenpoel \& E.W. Schurink (eds.), Research at grass roots: A primer for the caring professions, pp. 334-353, Van Schaik Publishers, Pretoria

Renfrew, J.W., 1997, Aggression and its causes: A biopsychosocial approach, Oxford University Press, New York.

Republic of South Africa, 1996a, Constitution of the Republic of South Africa, Act 108 of 1996, Typeface Media, Durban.

Republic of South Africa, 1996b, South African Schools Act, Act 84 of 1996, Government Printers, Pretoria.

Republic of South Africa, n.d., South African Schools Act Amendment Bill, Section 73(2), Government Printers, Pretoria.

Robbins, P.R., 2001, Anger, aggression and violence, Lawrence Erlbaum Associates, Mahwah.

Rossouw, J.P., 2007, 'The role of the governing body in school discipline', in R. Joubert \& E. Bray (eds.), Public school governance in South Africa, pp. 79-92, Centre for Education Law and Education Policy, Pretoria.

Shaffer, D.R. \& Kipp, K., 2010, Developmental psychology: Childhood and adolescence, 8th edn., Wadsworth, Belmont.

Singh, G.D., 2012, 'Managing learner aggression in rural secondary schools in the Empangeni district of KwaZulu-Natal', MEd dissertation, Dept. of Educational Leadership and Management, University of South Africa.

Spillane-Grieco, E., 2000, 'From parent verbal abuse to teenage physical aggression', Child and Adolescent Social Work Journal 17(6), 411-430.

Szyndrowski, D., 2005, 'The impact of domestic violence on adolescent aggression in the schools', Preventing School Failure 44(1), 9-12.

Valois, R.F., Macdonald, J.M., Bretous, L., Fischer, M.A. \& Drane, J.W., 2002, 'Risk factors and behaviours associated with adolescent violence and aggression', American Journal of Health Behaviour 26(6), 454-464.

Wiersma, W. \& Jurs, S.G., 2005, Research methods in education, 8th edn., Pearson Education, Boston. 